\title{
URGENSI PERPUSTAKAAN KAMPUS SEBAGAI MEDIA KETERBUKAAN INFORMASI PUBLIK DALAM MENCERDASKAN BANGSA
}

\author{
Moh Rosyid \\ Institut Agama Islam Negeri Kudus \\ mrosyid72@yahoo.co.id
}

\begin{abstract}
Abstrak
Tujuan ditulisnya naskah ini mengevaluasi peran manajemen pelayanan perpustakaan kampus, sudahkah memenuhi UU No 14 Tahun 2008 tentang Keterbukaan Informasi Publik (KIP) berpijak pada UU No 43 Tahun 2007 tentang Perpustakaan. Hal mendasar yang harus dipahami pustakawan kampus bahwa kewajiban Badan Publik (kampus) (1) menyediakan dan melayani permintaan informasi secara cepat, tepat waktu, biaya ringan/proporsional, dan cara sederhana; (2) membenahi sistem dokumentasi dan pelayanan informasi, (3) wajib membuka akses bagi setiap pemohon informasi publik (IP) untuk mendapatkan IP kecuali menghambat proses penegakan hukum, mengganggu kepentingan perlindungan hak atas kekayaan intelektual dan perlindungan dari persaingan usaha tidak sehat; membahayakan pertahanan dan keamanan negara, merugikan ketahanan ekonomi nasional dan kepentingan hubungan luar negeri, dan mengungkap rahasia pribadi. Ada pula hal yang boleh dipublis sesuai muatan UU KIP. Perpustakaan sudah saatnya sebagai sumber informasi tulis dan digital, tidak hanya sumber referensi ilmiah juga dinamika kampus dan produk hukum menyangkut kampus dengan kemudahan mengakses bagi publik, terutama
\end{abstract}


era digital. Kemudahan mengakses sumber data/informasi di perpustakaan kampus dengan kecanggihan teknologi informasi sebagai wujud peran serta perpustakaan ikut mencerdaskan kehidupan bangsa, tidak hanya mahasiswanya. Pelayanan yang tidak dibatasi ruang dan waktu sebagai langkah mengikuti dinamika global di era digital hingga terwujudnya kecerdasan anak bangsa.

Kata Kunci: informasi, keterbukaan informasi, mencerdaskan.

\section{A. Pendahuluan}

Amanat UUD 1945 Pasal 28 F bahwa setiap orang berhak untuk berkomunikasi dan memperoleh informasi untuk mengembangkan pribadi dan lingkungan sosialnya, serta berhak untuk mencari, memperoleh, memiliki, dan menyimpan informasi dengan menggunakan segala jenis saluran yang tersedia. Selain itu, untuk memberikan jaminan terhadap semua orang dalam memperoleh informasi sebagai kebutuhan pokok bagi publik yang keberadaan media informasi yang diakses dinamis seiring dinamika teknologi informasi. Menyikapi pentingnya informasi dan media menginformasikan, dan lembaga penyelenggara dan pengevaluasinya, pemerintah mengesahkan UU Nomor 14 Tahun 2008 tentang Keterbukaan Informasi Publik (KIP).

Dalam aspek lain, media bagi publik mengakses informasi dapat difasilitasi oleh lembaga di bawah naungan perguruan tinggi yakni perpustakaan. UU Nomor 43 Tahun 2007 tentang Perpustakaan, Pasal 1 (1) perpustakaan adalah institusi pengelola koleksi karya tulis, karya cetak, dan/atau karya rekam secara profesional dengan sistem yang baku guna memenuhi kebutuhan pendidikan, penelitian, pelestarian, informasi, dan rekreasi para pemustaka. ${ }^{1}$ Dengan demikian, perpustakaan tidak membatasi

${ }^{1}$ UU No 43/20017 Pasal 1 (9) pemustaka adalah pengguna perpustakaan (perseorangan, kelompok orang, masyarakat, atau lembaga) yang memanfaatkan fasilitas layanan perpustakaan. 
pelayanan pada pihak tertentu. ${ }^{2}$ Keberadaan perpustakaan kampus (terutama kampus negeri) kategori perpustakaan umum ${ }^{3}$ karena sumber pendanaan yang utama dari APBN sehingga dikategorikan badan publik. ${ }^{4}$ Beberapa poin dalam Pasal 1 (1) tersebut pokok yang dikaji dalam naskah ini adalah keberadaan institusi perpustakaan sebagai pemenuhan sumber informasi publik. Keberadaannya untuk memudahkan publik (tidak hanya mahasiswanya saja) mengetahui hal-hal yang perlu diketahuinya dalam wadah khusus. Perpustakaan tidak hanya melayani referensi seperti buku, tetapi informasi tentang dinamika perguruan tinggi (sebuah kampus) dan tatapemerintahan yang terkait dengan dunia perguruan tinggi. Keberadaan perpustakaan memiliki asas yakni pembelajaran sepanjang hayat, demokrasi, keadilan, keprofesionalan, keterbukaan, keterukuran, dan kemitraan (Pasal 2). Perpustakaan didirikan bertujuan memberikan layanan kepada pemustaka, meningkatkan kegemaran membaca, serta memperluas wawasan dan pengetahuan untuk mencerdaskan kehidupan bangsa (Pasal 4). Fokus naskah ini lebih mendalami aspek keterbukaan dan memperluas wawasan pemustaka.

Perpustakaan perlu pula memfasilitasi pemustaka warga difabel dengan menyediakan media baca layar, memperbesar tampilannya, web braille translator, perangkat lunak untuk konversi teks ke suara, web untuk konversi dari suara ke teks, dan optical character recognition. ${ }^{5}$ Melayaninya berpijak pada International Federation of Library and Institutions (IFLA) -organisasi federasi

${ }^{2}$ UU No 14/2008 Pasal 2 (1) setiap Informasi Publik bersifat terbuka dan dapat diakses oleh setiap pengguna Informasi Publik (IP).

${ }^{3}$ UU No 43/20017 Pasal 1 (6) perpustakaan umum adalah perpustakaan yang diperuntukkan bagi masyarakat luas sebagai sarana pembelajaran sepanjang hayat tanpa membedakan umur, jenis kelamin, suku, ras, agama, dan status sosial-ekonomi.

${ }^{4}$ UU No 14/2008 Pasal 1 (3) Badan Publik adalah lembaga eksekutif, legislatif, yudikatif, dan badan lain yang fungsi dan tugas pokoknya berkaitan dengan penyelenggaraan negara, yang sebagian atau seluruh dananya bersumber dari APBN dan/atau APBD atau organisasi nonpemerintah sepanjang sebagian atau seluruh dananya bersumber dari APBN dan/atau APBD, sumbangan masyarakat, dan/atau luar negeri.

${ }^{5}$ Heri Abi Burachman Hakim dan Wiyarsih. Kompetensi Pustakawan dan Optimalisasi Teknologi Informasi untuk Meningkatkan Kualitas Layanan 
yang terbentuk dari berbagai instansi perpustakaan dalam ruang lingkup internasional ada dua puluh komponen terbagi dalam tiga kategori yakni standar akses fisik, format media, layanan dan komunikasi.

Ragam kebutuhan setiap individu sangat ditentukan oleh profesi, lingkungan, dan gaya hidup dalam rutinitas sehari-hari. Keberadaan sumber informasi sebagai modal mengakses informasi, sudah selazimnya perpustakaan memberi ruang sebagai sumber informasi dengan kemudahan bagi pihak manapun (tidak hanya bagi dosen dan mahasiswa) yang berkepentingan untuk mengakses informasi berbagai hal yang dilakukan kampusnya. Hal ini didorong oleh hak dasar manusia berupa Hak untuk Tahu Internasional (International Right to Know Day) yang diperingati setiap 28 September. Menurut Al-Afghani, transparansi dan kebebasan informasi dianggap sebagai bagian dari hak asasi manusia dan dipercaya mutlak diperlukan dalam suatu negara demokratis untuk membasmi korupsi. Transparansi dan akses informasi diperlukan agar pasar dapat bekerja secara baik. Agenda transparansi sealur antara lembaga donor internasional dengan gerakan masyarakat sipil. Transparansi demokrasi berkeyakinan bahwa informasi perlu dibuka sebagai salah satu bentuk pertanggungjawaban pemerintah kepada rakyat dan perlunya perlindungan terhadap kerahasiaan. ${ }^{6}$ Sejak September 2011, delapan negara menginisiatori open government partnership yakni sebuah upaya bersama mewujudkan pemerintahan yang lebih terbuka dan mengajak partisipasi publik. Kedelapan negara tersebut yakni Amerika, Inggris, Meksiko, Indonesia, Filipina, Brasil, Norwegia, dan Afrika Selatan. Perdana Menteri Inggris David Cameron membentuk tim Reformasi dan Efisiensi (ERG) untuk efesiensi dan reformasi anggaran sebagai layanan publik. Komitmen tersebut dalam hal (1) keterbukaan data untuk akuntabilitas, perbaikan layanan publik, dan pertumbuhan

Pemustaka Difabel. Jurnal Ikatan Pustakawan Indonesia. Vol.3, No.1 Tahun 2018, hlmn.61.

${ }^{6}$ Mohammad Mova Alafghani. Dua Kubu Transparansi. Republika, 28 September 2013, hlm.6. 
ekonomi, (2) integritas pemerintah dalam menanggulangi korupsi melalui transparansi pemerintahan, (3) transparansi fiskal agar rakyat mengetahui peruntukan pajak yang dibayarkan, pemberdayaan warga melalui perubahan cara komunikasi warga dengan pemerintah, (5) transparansi sumber daya alam (SDA) agar pemasukan negara digunakan untuk kepentingan publik. ${ }^{7}$

Naskah ini merupakan upaya penulis mengingatkan kembali pentingnya pengelola perguruan tinggi agar perpustakaannya didesain juga sebagai media menginformasikan seputar kampusnya dan tatapemerintahan perihal perguruan tinggi pada publik secara luas dan tidak terbatas, yakni dibatasi oleh undang-undang keterbukaan informasi publik. Hal yang perlu dipahami publik dan pimpinan kampus adalah hal apa yang boleh difasilitasi dan hal yang tidak untuk diinformasikan pada publik berdasarkan batasan dalam UU KIP. Dengan demikian, optimalnya pelaksanaan UU KIP sangat tergantung kinerja pengelola perpustakaan kampus, keinginan publik memanfaatkannya, dan peran civil society sebagai lembaga Nation Government Organization (NGO/LSM) yang mengontrol kinerja pengelola perpustakaan kampus. Kiprah perpustakaan di atas dapat mempercepat perwujudan pemerintahan yang terbuka yang merupakan upaya strategis mencegah praktik korupsi, kolusi, dan nepotisme (KKN), terciptanya pemerintahan yang baik (good governance), dan terwujudnya pelayanan informasi publik yang bijaksana dan mendewasakan.

\section{Memahami Keterbukaan Informasi Publik}

Muatan UUD 1945 Pasal 28 F bahwa setiap orang berhak untuk berkomunikasi dan memperoleh informasi untuk mengembangkan pribadi dan lingkungan sosialnya, serta berhak untuk mencari, memperoleh, memiliki, dan menyimpan informasi dengan menggunakan segala jenis saluran yang tersedia. Untuk memberikan jaminan terhadap semua orang dalam memperoleh informasi, UU KIP sangat diperlukan yang berfungsi memenuhi

\footnotetext{
${ }^{7}$ Kompas, 13 April 2014.
} 
hak warga negara agar terpenuhi informasi. Hal ini merupakan hak asasi manusia sebagai salah satu wujud dari kehidupan berbangsa dan bernegara yang demokratis karena salah satu elemen penting dalam mewujudkan penyelenggaraan negara yang terbuka adalah hak publik untuk memperoleh informasi sesuai dengan peraturan perundangan. Hak atas informasi menjadi sangat penting karena makin terbuka penyelenggaraan negara untuk diawasi publik, penyelenggaraan negara tersebut makin dapat dipertanggungjawabkan. Hak setiap orang untuk memperoleh informasi juga relevan untuk meningkatkan kualitas pelibatan masyarakat dalam proses pengambilan keputusan publik. Partisipasi atau pelibatan masyarakat tidak banyak berarti tanpa jaminan KIP. Dalam konteks perpustakaan kampus, pihak manajemen memenuhi keinginan publik mengetahui tentang kampus dan tatapemerintahan tentang perguruan tinggi, sesuai batasan dalam perundangan.

Keberadaan UU KIP sangat penting sebagai landasan hukum yang berkaitan dengan (1) hak setiap orang untuk memperoleh informasi; (2) kewajiban Badan Publik (BP) menyediakan dan melayani permintaan informasi secara cepat, tepat waktu, biaya ringan/proporsional, dan cara sederhana; (3) pengecualian bersifat ketat dan terbatas; (4) kewajiban BP untuk membenahi sistem dokumentasi dan pelayanan informasi. Pasal 1 (3) BP adalah lembaga eksekutif, legislatif, yudikatif, dan badan lain yang fungsi dan tugas pokoknya berkaitan dengan penyelenggaraan negara, yang sebagian atau seluruh dananya bersumber dari APBN dan/ atau APBD, atau organisasi nonpemerintah sepanjang sebagian atau seluruh dananya bersumber dari APBN dan/atau APBD, sumbangan masyarakat, dan/atau luar negeri. Setiap BP mempunyai kewajiban untuk membuka akses atas informasi publik yang berkaitan dengan BP untuk masyarakat luas. Lingkup BP dalam UU KIP meliputi lembaga eksekutif, yudikatif, legislatif, serta penyelenggara negara lainnya yang mendapatkan dana dari APBN/ APBD dan mencakup pula organisasi nonpemerintah, baik yang 
berbadan hukum maupun yang tidak berbadan hukum, seperti lembaga swadaya masyarakat (LSM), perkumpulan, serta organisasi lainnya yang mengelola atau menggunakan dana yang sebagian atau seluruhnya bersumber dari APBN/APBD, sumbangan masyarakat, dan/atau luar negeri. Melalui mekanisme dan pelaksanaan prinsip keterbukaan akan tercipta pemerintahan yang baik dan peran serta masyarakat yang transparan dan akuntabilitas yang tinggi sebagai salah satu prasyarat mewujudkan demokrasi yang hakiki.

Dengan membuka akses publik terhadap informasi diharapkan BP termotivasi untuk bertanggung jawab dan berorientasi pada pelayanan rakyat yang sebaik-baiknya. Dengan demikian, hal itu dapat mempercepat perwujudan pemerintahan yang terbuka yang merupakan upaya strategis mencegah praktik korupsi, kolusi, dan nepotisme (KKN), dan terciptanya pemerintahan yang baik (good governance). Informasi merupakan kebutuhan pokok setiap orang bagi pengembangan pribadi dan lingkungan sosialnya serta merupakan bagian penting bagi ketahanan nasional. Pasal 1 (1) Informasi adalah keterangan, pernyataan, gagasan, dan tanda-tanda yang mengandung nilai, makan, dan pesan, baik data, fakta maupun penjelasannya yang dapat dilihat, didengar, dan dibaca yang disajikan dalam berbagai kemasan dan format sesuai dengan perkembangan teknologi informasi dan komunikasi secara elektronik ataupun nonelektronik. Pasal 1 (2) Informasi Publik (IP) adalah informasi yang dihasilkan, disimpan, dikelola, dikirim, dan/atau diterima oleh suatu badan publik yang berkaitan dengan penyelenggara dan penyelenggaraan negara dan/atau penyelenggara dan penyelenggaraan badan publik lainnya yang sesuai dengan UU ini serta informasi lain yang berkaitan dengan kepentingan publik.

Hak memperoleh informasi merupakan hak asasi manusia dan KIP merupakan salah satu ciri penting negara demokratis yang menjunjung tinggi kedaulatan rakyat untuk mewujudkan penyelenggaraan negara yang baik. KIP merupakan sarana dalam mengoptimalkan pengawasan publik terhadap penyelenggaraan 
negara dan lainnya dan segala sesuatu yang berakibat pada kepentingan publik. Pengelolaan IP merupakan salah satu upaya untuk mengembangkan masyarakat informasi yang dapat dijadikan mengakses dinamika menuju terpenuhinya kebutuhan hidup warga negara, khususnya di bidang pendidikan. UU KIP di dalamnya mewajibkan pemerintah membentuk Komisi Informasi Publik (KIP) yang berperan mendorong transparansi informasi di lembaga pemerintahan pusat dan daerah (pemda) dan melakukan edukasi terkait era keterbukaan informasi publik pada publik. Lembaga bentukan pemerintah ini memiliki tugas dan wewenang sebagaimana amanat UU Nomor 14 Tahun 2008. Harapannya, agar masyarakat mengetahui perihal informasi apa yang boleh diketahui/dibuka maupun yang tidak boleh diketahui publik. Konsekuensinya, anggota KIP harus bekerja secara profesional dan bekerja maksimal agar masyarakat merasakan keberadaannya. Dengan demikian, disahkannya UU Nomor 14 Tahun 2008 tentang Keterbukaan Informasi Publik (KIP) yang diberlakukan sejak 2010 menjadi hal penting untuk ditelaah sejauhmana realisasinya untuk dijadikan sumber informasi bagi publik, khususnya di bidang pendidikan tinggi.

\section{Asas dan Tujuan Informasi Publik dalam UU Nomor 14 Tahun 2008}

Pasal 2 (1) setiap Informasi Publik (IP) bersifat terbuka dan dapat diakses oleh setiap pengguna IP, ${ }^{8}$ (2) IP yang dikecualikan bersifat ketat dan terbatas, (3) setiap IP harus dapat diperoleh setiap pemohon IP dengan cepat dan tepat waktu, biaya ringan, dan cara sederhana, (4) IP yang dikecualikan bersifat rahasia sesuai dengan UU, kepatutan, dan kepentingan umum didasarkan pada pengujian tentang konsekuensi yang timbul apabila suatu informasi diberikan kepada masyarakat serta setelah dipertimbangkan dengan saksama

${ }^{8}$ Pasal 1 (2) IP adalah informasi yang dihasilkan, disimpan, dikelola, dikirim, dan/atau diterima oleh suatu badan publik yang berkaitan dengan penyelenggara dan penyelenggaraan negara dan/atau penyelenggara dan penyelenggaraan badan publik lainnya yang sesuai dengan UU KIP serta informasi lain yang berkaitan dengan kepentingan publik. 
bahwa menutup IP dapat melindungi kepentingan yang lebih besar daripada membukanya atau sebaliknya. Pasal 3 tujuan IP untuk (a) menjamin hak warga negara untuk mengetahui rencana pembuatan kebijakan publik, program kebijakan publik, dan proses pengambilan keputusan publik, serta alasan pengambilan suatu keputusan publik; (b) mendorong partisipasi masyarakat dalam proses pengambilan kebijakan publik; (c) meningkatkan peran aktif masyarakat dalam pengambilan kebijakan publik dan pengelolaan BP yang baik; (d) mewujudkan penyelenggaraan negara yang baik, yaitu transparan, efektif dan efisien, akuntabel serta dapat dipertanggungjawabkan; (e) mengetahui alasan kebijakan publik yang mempengaruhi hajat hidup orang banyak; (f) mengembangkan ilmu pengetahuan dan mencerdaskan kehidupan bangsa; ${ }^{9}$ dan (g) meningkatkan pengelolaan dan pelayanan informasi di lingkungan BP untuk menghasilkan layanan informasi yang berkualitas.

Pasal 4 (1) setiap orang berhak memperoleh IP sesuai ketentuan UU ini, (2) setiap orang berhak (a) melihat dan mengetahui IP; (b) menghadiri pertemuan publik yang terbuka untuk umum untuk memperoleh IP; (c) mendapatkan salinan IP melalui permohonan sesuai dengan UU KIP; dan/atau (d) menyebarluaskan IP sesuai dengan peraturan perundangan, (3) setiap pemohon IP berhak mengajukan permintaan IP disertai alasan permintaan tersebut, (4) stiap pemohon IP berhak mengajukan gugatan ke pengadilan apabila dalam memperoleh IP mendapat hambatan atau kegagalan sesuai ketentuan UU KIP. Pasal 5 (1) pengguna IP wajib menggunakan IP sesuai dengan ketentuan perundangan. (2) pengguna IP wajib mencantumkan sumber dari mana ia memperoleh IP, baik yang digunakan untuk kepentingan sendiri maupun keperluan publikasi sesuai dengan ketentuan peraturan perundangan. Pasal 6 (1) BP berhak menolak memberikan informasi yang dikecualikan sesuai dengan ketentuan peraturan perundangan, ${ }^{10}$ (2) BP berhak menolak memberikan IP

\footnotetext{
${ }^{9}$ Fokus naskah ini pada upaya mencerdaskan kehidupan bangsa.

${ }^{10}$ Perguruan tinggi (terutama negeri) merupakan badan publik yang di dalamnya terdapat lembaga perpustakaan sebagai media publikasi perihal hal-
} 
apabila tidak sesuai dengan ketentuan peraturan perundangan, (3) IP yang tidak dapat diberikan oleh BP, sebagaimana dimaksud pada ayat 1 adalah (a) informasi yang dapat membahayakan negara; (b) informasi yang berkaitan dengan kepentingan perlindungan usaha dari persaingan usaha tidak sehat; (c) informasi yang berkaitan dengan hak pribadi; (d) informasi yang berkaitan dengan rahasia jabatan; dan/atau (e) IP yang diminta belum dikuasai atau didokumentasikan. Pasal 7 (1) BP wajib menyediakan, memberikan dan/atau menerbitkan IP yang berada di bawah kewenangannya kepada Pemohon IP, selain informasi yang dikecualikan sesuai dengan ketentuan UU KIP. (2) BP wajib menyediakan IP yang akurat, benar, dan tidak menyesatkan. (3) Untuk melaksanakan kewajiban sebagaimana dimaksud ayat 2, BP harus membangun dan mengembangkan sistem informasi dan dokumentasi untuk mengelola IP secara baik dan efisien sehingga dapat diakses dengan mudah. (4) BP wajib membuat pertimbangan secara tertulis setiap kebijakan yang diambil untuk memenuhi hak setiap orang atas IP, (5) Pertimbangan sebagaimana dimaksud ayat 4 antara lain memuat pertimbangan politik, ekonomi, sosial, budaya, dan/atau pertahanan dan keamanan negara. (6) Dalam rangka memenuhi kewajiban sebagaimana dimaksud ayat 1 s.d 4 BP dapat memanfaatkan sarana dan/atau media elektronik dan nonelektronik. Pasal 8 Kewajiban BP yang berkaitan dengan kearsipan dan pendokumentasian IP dilaksanakan berdasarkan peraturan perundangan.

\section{Informasi yang Wajib Disediakan dan Diumumkan Badan Publik}

Pasal 9 (1) setiap BP wajib mengumumkan IP secara berkala, (2) IP sebagaimana dimaksud pada ayat (1) meliputi (a) informasi yang berkaitan dengan BP; (b) informasi mengenai kegiatan dan kinerja BP terkait; (c) informasi mengenai laporan keuangan; dan/ atau (d) informasi lain yang diatur dalam peraturan perundangan. (3) Kewajiban memberikan dan menyampaikan IP sebagaimana dimaksud ayat 2 dilakukan paling singkat 6 bulan sekali. (4)

hal yang tidak dikecualikan, sebagaimana diatur dalam Pasal 6 UU KIP. 
Kewajiban menyebarluaskan IP sebagaimana dimaksud ayat 1 , disampaikan dengan cara yang mudah dijangkau oleh masyarakat dan dalam bahasa yang mudah dipahami. (5) Cara sebagaimana dimaksud ayat 4 ditentukan lebih lanjut oleh Pejabat Pengelola Informasi dan Dokumentasi di BP terkait. (6) Ketentuan lebih lanjut mengenai kewajiban BP memberikan dan menyampaikan IP secara berkala sebagaimana dimaksud pada ayat 1, 2, dan 3 diatur dengan Petunjuk Teknis Komisi Informasi. Dengan demikian, lembaga kampus pun harus melaksanakan amanat Pasal 9 tersebut.

\section{Informasi yang Wajib Diumumkan dan Tersedia secara Serta- merta}

Pasal 10 (1) BP wajib mengumumkan secara serta-merta suatu informasi yang dapat mengancam hajat hidup orang banyak dan ketertiban umum. (2) Kewajiban menyebarluaskan IP sebagaimana dimaksud pada ayat (1) disampaikan dengan cara yang mudah dijangkau oleh masyarakat dan dalam bahasa yang mudah dipahami. Pasal 11 (1) BP wajib menyediakan informasi publik setiap saat yang meliputi (a) daftar seluruh informasi publik yang berada di bawah penguasaannya, tidak termasuk informasi yang dikecualikan; (b) hasil keputusan BP dan pertimbangannya; (c) seluruh kebijakan yang ada berikut dokumen pendukungnya; (d) rencana kerja proyek termasuk di dalamnya perkiraan pengeluaran tahunan BP; (e) perjanjian BP dengan pihak ketiga; (f) informasi dan kebijakan yang disampaikan Pejabat Publik dalam pertemuan yang terbuka untuk umum; (g) prosedur kerja pegawai BP yang berkaitan dengan pelayanan masyarakat; dan/ atau (h) laporan mengenai pelayanan akses informasi publik sebagaimana diatur dalam UU ini. (2) IP yang telah dinyatakan terbuka bagi masyarakat berdasarkan mekanisme keberatan dan/ atau penyelesaian sengketa sebagaimana dimaksud dalam Pasal 48, 49, dan 50 dinyatakan sebagai IP yang dapat diakses oleh pengguna informasi publik. (3) Ketentuan lebih lanjut mengenai tata cara pelaksanaan kewajiban badan publik menyediakan informasi publik yang dapat diakses oleh pengguna IP sebagaimana 
dimaksud pada ayat 1 dan 2 diatur dengan Petunjuk Teknis Komisi Informasi. Pasal 12 setiap tahun BP wajib mengumumkan layanan informasi meliputi (a) jumlah permintaan informasi yang diterima; (b) waktu yang diperlukan BP dalam memenuhi setiap permintaan informasi; (c) jumlah pemberian dan penolakan permintaan informasi; dan/atau (d) alasan penolakan permintaan informasi. Pasal 13 (1) Untuk mewujudkan pelayanan cepat, tepat, dan sederhana setiap BP (a) menunjuk Pejabat Pengelola Informasi dan Dokumentasi; dan (b) membuat dan mengembangkan sistem penyediaan layanan informasi secara cepat, mudah, dan wajar sesuai dengan petunjuk teknis standar layanan informasi publik yang berlaku secara nasional. (2) Pejabat pengelola informasi dan dokumentasi sebagaimana ayat 1 huruf a dibantu oleh pejabat fungsional. Pasal 14 IP yang wajib disediakan oleh Badan Usaha Milik Negara (BUMN), Badan Usaha Milik Daerah (BUMD) dan/ atau badan usaha lainnya yang dimiliki oleh negara dalam UU ini adalah (a) nama dan tempat kedudukan, maksud dan tujuan serta jenis kegiatan usaha, jangka waktu pendirian, dan permodalan, sebagaimana tercantum dalam anggaran dasar; (b) nama lengkap pemegang saham, anggota direksi, dan anggota dewan komisaris perseroan; (c) laporan tahunan, laporan keuangan, neraca laporan laba rugi, dan laporan tanggung jawab sosial perusahaan yang telah diaudit; (d) hasil penilaian oleh auditor eksternal, lembaga pemeringkat kredit dan lembaga pemeringkat lainnya; (e) sistem dan alokasi dana remunerasi anggota komisaris/dewan pengawas dan direksi; (f) mekanisme penetapan direksi dan komisaris/ dewan pengawas; (g) kasus hukum yang berdasarkan UU terbuka sebagai informasi publik; (h) pedoman pelaksanaan tata kelola perusahaan yang baik berdasarkan prinsip transparansi, akuntabilitas, pertanggungjawaban, kemandirian, dan kewajaran; (i) pengumuman penerbitan efek yang bersifat utang; ( $j$ ) penggantian akuntan yang mengaudit perusahaan; $(\mathrm{k})$ perubahan tahun fiskal perusahaan; (l) kegiatan penugasan pemerintah dan/atau kewajiban pelayanan umum atau subsidi; (m) mekanisme pengadaan barang 
dan jasa; dan/atau (n) informasi lain yang ditentukan oleh UU yang berkaitan dengan BUMN/BUMD. Dengan demikian, lembaga kampus pun harus melaksanakan amanat Pasal 10-13 tersebut.

\section{Informasi yang Dikecualikan}

Pasal 17 setiap BP wajib membuka akses bagi setiap pemohon IP untuk mendapatkan IP, kecuali (a) IP yang apabila dibuka dan diberikan kepada pemohon IP dapat menghambat proses penegakan hukum, yaitu informasi yang dapat (1) menghambat proses penyelidikan dan penyidikan suatu tindak pidana; (2) mengungkapkan identitas informan, pelapor, saksi, dan/atau korban yang mengetahui adanya tindak pidana; (3) mengungkapkan data intelijen kriminal dan rencana yang berhubungan dengan pencegahan dan penanganan segala bentuk kejahatan transnasional; (4) membahayakan keselamatan dan kehidupan penegak hukum dan/atau keluarganya; dan/atau (5) membahayakan keamanan peralatan, sarana, dan/atau prasarana penegak hukum. (b) IP yang apabila dibuka dan diberikan kepada pemohon IP dapat mengganggu kepentingan perlindungan hak atas kekayaan intelektual dan perlindungan dari persaingan usaha tidak sehat; (c) IP yang apabila dibuka dan diberikan kepada pemohon IP dapat membahayakan pertahanan dan keamanan negara, yaitu (1) informasi tentang strategi, intelijen, operasi, taktik dan teknik yang berkaitan dengan penyelenggaraan sistem pertahanan dan keamanan negara, meliputi tahap perencanaan, pelaksanaan dan pengakhiran atau evaluasi dalam kaitan dengan ancaman dari dalam dan luar negeri; (2) dokumen yang memuat tentang strategi, intelijen, operasi, teknik dan taktik yang berkaitan dengan penyelenggaraan sistem pertahanan dan keamanan negara yang meliputi tahap perencanaan, pelaksanaan dan pengakhiran atau evaluasi; (3) jumlah, komposisi, disposisi atau dislokasi kekuatan dan kemampuan dalam penyelenggaraan sistem pertahanan dan keamanan negara serta rencana pengembangannya; (4) gambar dan data tentang situasi dan keadaan pangkalan dan/atau instalasi militer; (5) data perkiraan kemampuan militer dan pertahanan 
negara lain terbatas pada segala tindakan dan/atau indikasi negara tersebut yang dapat membahayakan kedaulatan NKRI dan/atau data terkait kerja sama militer dengan negara lain yang disepakati dalam perjanjian tersebut sebagai rahasia atau sangat rahasia; (6) sistem persandian negara; dan/atau (7) sistem intelijen negara, (d) IP yang apabila dibuka dan diberikan kepada pemohon IP dapat mengungkapkan kekayaan alam Indonesia; (e) IP yang apabila dibuka dan diberikan kepada pemohon IP dapat merugikan ketahanan ekonomi nasional (1) rencana awal pembelian dan penjualan mata uang nasional atau asing, saham dan aset vital milik negara; (2) rencana awal perubahan nilai tukar, suku bunga, dan model operasi institusi keuangan; (3) rencana awal perubahan suku bunga bank, pinjaman pemerintah, perubahan pajak, tarif atau pendapatan negara/daerah lainnya; (4) rencana awal penjualan atau pembelian tanah atau properti; (5) rencana awal investasi asing; (6) proses dan hasil pengawasan perbankan, asuransi atau lembaga keuangan lainnya; dan/atau (7) hal-hal yang berkaitan dengan proses pencetakan uang. (f) IP yang apabila dibuka dan diberikan kepada pemohon IP, dapat merugikan kepentingan hubungan luar negeri (1) posisi, daya tawar dan strategi yang akan dan telah diambil oleh negara dalam hubungannya dengan negosiasi internasional; (2) korespondensi diplomatik antarnegara; (3) sistem komunikasi dan persandian yang dipergunakan dalam menjalankan hubungan internasional; dan/atau (4) perlindungan dan pengamanan infrastruktur strategis Indonesia di luar negeri. (g) IP yang apabila dibuka dapat mengungkapkan isi akta otentik yang bersifat pribadi dan kemauan terakhir ataupun wasiat seseorang; (h) IP yang apabila dibuka dan diberikan kepada pemohon IP dapat mengungkap rahasia pribadi, yaitu (1) riwayat dan kondisi anggota keluarga; (2) riwayat, kondisi dan perawatan, pengobatan kesehatan fisik, dan psikis seseorang; (3) kondisi keuangan, aset, pendapatan, dan rekening bank seseorang; (4) hasil-hasil evaluasi sehubungan dengan kapabilitas, intelektualitas, dan rekomendasi kemampuan seseorang; dan/atau (5) catatan yang menyangkut pribadi seseorang 
yang berkaitan dengan kegiatan satuan pendidikan formal dan satuan pendidikan nonformal. (i) memorandum atau surat-surat antar-BP atau intra BP yang menurut sifatnya dirahasiakan kecuali atas putusan Komisi Informasi atau pengadilan; (j) informasi yang tidak boleh diungkapkan berdasarkan UU. Hal-hal yang dipublikasikan dalam muatan publikasi di perpustakaan kampus harus berpegang teguh pada hal-hal di atas.

\section{Informasi yang Tidak Dikecualikan}

Pasal 18 (1) tidak termasuk dalam kategori informasi yang dikecualikan adalah informasi berikut (a) putusan badan peradilan; (b) ketetapan, keputusan, peraturan, surat edaran, ataupun bentuk kebijakan lain, baik yang tidak berlaku mengikat maupun mengikat ke dalam ataupun ke luar serta pertimbangan lembaga penegak hukum; (c) surat perintah penghentian penyidikan (SP 3) atau penuntutan; (d) rencana pengeluaran tahunan lembaga penegak hukum; (e) laporan keuangan tahunan lembaga penegak hukum; (f) laporan hasil pengembalian uang hasil korupsi; dan/atau (g) informasi lain sebagaimana dimaksud dalam Pasal 11 ayat (2). ${ }^{11}$ (2) Tidak termasuk informasi yang dikecualikan sebagaimana dimaksud Pasal 17 huruf g dan h, antara lain apabila (a) pihak yang rahasianya diungkap memberikan persetujuan tertulis; dan/atau (b) pengungkapan berkaitan dengan posisi seseorang dalam jabatan publik. (3) Dalam hal kepentingan pemeriksaan perkara pidana di pengadilan, kepolisian, Jaksa Agung, Ketua MA, Ketua KPK, dan/atau Pimpinan Lembaga Negara Penegak Hukum lainnya yang diberi kewenangan oleh UU dapat membuka informasi yang dikecualikan sebagaimana dimaksud dalam Pasal 17 huruf a, b, c, d, e, f, i, dan j. (4) Pembukaan informasi yang dikecualikan sebagaimana ayat 3 dilakukan dengan cara mengajukan permintaan izin kepada Presiden. (5) Permintaan izin sebagaimana dimaksud pada ayat 3 dan 4 untuk kepentingan

${ }^{11}$ Pasal 11 ayat (2) IP yang telah dinyatakan terbuka bagi masyarakat berdasarkan mekanisme keberatan dan/atau penyelesaian sengketa sebagaimana dimaksud dalam Pasal 48, 49, dan 50 dinyatakan sebagai IP yang dapat diakses oleh pengguna informasi publik. 
pemeriksaan perkara perdata yang berkaitan dengan keuangan atau kekayaan negara di pengadilan, permintaan izin diajukan oleh Jaksa Agung sebagai pengacara negara kepada Presiden. (6) Izin tertulis sebagaimana dimaksud pada ayat 3, 4, dan 5 diberikan oleh Presiden kepada Kapolri, Jaksa Agung, Ketua KPK, Pimpinan Lembaga Negara Penegak Hukum lainnya atau Ketua MA. (7) Dengan mempertimbangkan kepentingan pertahanan dan keamanan negara dan kepentingan umum, Presiden dapat menolak permintaan informasi yang dikecualikan sebagaimana dimaksud ayat 3, 4, dan 5. Pasal 19 Pejabat Pengelola Informasi dan dokumentasi di setiap badan publik wajib melakukan pengujian tentang konsekuensi sebagaimana dimaksud dalam Pasal 17 dengan saksama dan penuh ketelitian sebelum menyatakan informasi publik tertentu dikecualikan untuk diakses oleh setiap orang.

\section{Mekanisme Memperoleh Informasi}

Pasal 21 Mekanisme untuk memperoleh informasi publik didasarkan pada prinsip cepat, tepat waktu, dan biaya ringan. Pasal 22 (1) setiap pemohon IP dapat mengajukan permintaan untuk memperoleh IP kepada BP terkait secara tertulis atau tidak tertulis, (2) BP wajib mencatat nama dan alamat pemohon IP, subjek dan format informasi serta cara penyampaian informasi yang diminta oleh pemohon IP, (3) BP yang bersangkutan wajib mencatat permintaan IP yang diajukan secara tidak tertulis. (4) BP terkait wajib memberikan tanda bukti penerimaan permintaan IP sebagaimana ayat 1 dan 3 berupa nomor pendaftaran pada saat permintaan diterima. (5) Dalam hal permintaan disampaikan secara langsung atau melalui surat elektronik, nomor pendaftaran diberikan saat penerimaan permintaan. (6) Dalam hal permintaan disampaikan melalui surat, pengiriman nomor pendaftaran dapat diberikan bersamaan dengan pengiriman informasi. (7) Paling lambat 10 hari kerja sejak diterimanya permintaan, BP yang bersangkutan wajib menyampaikan pemberitahuan tertulis yang berisikan (a) informasi yang diminta berada di bawah penguasaannya ataupun tidak; (b) BP wajib memberitahukan 
BP yang menguasai informasi yang diminta apabila informasi yang diminta tidak berada di bawah penguasaannya dan BP yang menerima permintaan mengetahui keberadaan informasi yang diminta; (c) penerimaan atau penolakan permintaan dengan alasan yang tercantum sebagaimana dimaksud Pasal 17; (d) dalam hal permintaan diterima seluruhnya atau sebagian dicantumkan materi informasi yang akan diberikan; (e) dalam hal suatu dokumen mengandung materi yang dikecualikan sebagaimana dimaksud dalam Pasal 17, maka informasi yang dikecualikan tersebut dapat dihitamkan dengan disertai alasan dan materinya; (f) alat penyampai dan format informasi yang akan diberikan; dan/atau (g) biaya serta cara pembayaran untuk memperoleh informasi yang diminta. (8) BP yang bersangkutan dapat memperpanjang waktu untuk mengirimkan pemberitahuan sebagaimana dimaksud ayat 7, paling lambat tujuh hari kerja berikutnya dengan memberikan alasan secara tertulis.

\section{Pelaksanaan Keterbukaan Informasi Publik}

Sebagian besar badan publik belum siap melaksanakan UU KIP. Sebagaimana hasil kerja lapangan Sekretariat Nasional Forum Indonesia untuk Transparansi Anggaran (Seknas Fitra) yang meminta informasi anggaran pada 119 badan publik tingkat nasional dari kementerian, lembaga negara hingga parpol hasilnya mengecewakan. Dari 118 badan publik, 54 atau 45,8 persen memberikan cukup informasi, meskipun sejumlah kecil yang memberi informasi setelah diajukan keberatan dan dilakukan mediasi. Sebagian besar parpol dan lembaga nonstruktural tidak mau memberikan informasi anggaran. Dari 10 parpol yang memiliki kursi di DPR, hanya 2 yang merespon permintaan terkait informasi anggaran yang mereka terima dari APBN yakni PKS dan Partai Gerindra. Tujuh partai lain tak memberi respon meski sudah disampaikan keberatan ke Komisi Informasi Pusat (KIP). Setelah mediasi oleh KIP, PKB mau memberikan informasi. Terdapat 4 kasus KIP yang ditangani KIP dan mendapat putusan berkekuatan hukum tetap yakni harus dibuka yaitu dana BOS 
(Bantuan Operasional Sekolah), rekening tak wajar milik petinggi Polri, kontrak kerja sama BUMD dengan pihak ketiga di Blok Cepu, dan lembar kerja jawaban komputer seleksi CPNS. ${ }^{12}$ Ketua KIP Pusat Abdulhamid Dipopramono menyatakan, sebagian besar organisasi badan publik belum mempunyai kesadaran untuk memberikan informasi seluas-luasnya kepada masyarakat, bahkan cenderung menahan informasi, tak bedanya terhadap sesama komisi negara, termasuk KIP. Kamis 12 Desember 2013 Wapres Boediono menganugerahkan Keterbukaan Informasi Badan Publik 2013 di Istana Wapres. Peserta dibagi dalam empat kategori, yakni badan publik pemerintah, badan publik provinsi, badan publik BUMN, dan badan publik parpol nasional. Dari 12 parpol yang dikirimi kuesioner, hanya PDI-P yang mengembalikan pada KIP. ${ }^{13}$ Berbeda dengan Kabupaten Batang Jateng yang menggelar Festival Anggaran agar publik mengetahui program apa saja yang dikerjakan pemda. Daftar anggaran dipajang di halaman kantor Bupati Yoyok Riyo Sudibyo -dilantik Januari 2012- pada 12 s.d 14 Februari 2014. Gaji bupati per bulan Rp 6.231.700 dan wabup Rp 5.263.700, dan gaji jajaran birokrasi pun dipampang. Tujuan membuka APBD untuk mempertanggungjawabkan kinerjanya kepada masyarakat. ${ }^{14}$ KIP Jawa Tengah pada Senin 16 Desember 2013 mengumumkan peringkat daftar transparansi badan publik pemerintah kab/kota di Jateng. Kabupaten Rembang meraih nilai tertinggi (terbaik) dengan skor 93, Grobogan dengan skor 88, dan Pemkot Surakarta dengan skor 84, disusul Jepara dan Pemkot Semarang dengan skor samasama 82. Urutan terbawah ditempati Pemkab Purbalingga dengan nilai 56. Pemeringkatan berdasarkan dua sumber yakni hasil monitoring dan evaluasi (monev) KIP Jateng di $35 \mathrm{kab} / \mathrm{kota}$ dan penilaian atas konten website pemerintah daerah. Monev mencatat kelengkapan regulasi tentang pejabat pengelola informasi dan dokumentasi (PPID) dan sarana meliputi meja pelayanan informasi dan papan pengumuman. Regulasi PPID meliputi peraturan dan

\footnotetext{
${ }^{12}$ Kompas, 3 Agustus 2011, hlm.4.

${ }_{13}$ Kompas, 13 Desember 2013, hlm.2.

${ }^{14}$ Kompas, 1 Maret 2014.
} 
surat keputusan bupati/wali kota, standar operasional prosedur (SOP) pelayanan informasi dan uji konsekuensi yang menghasilkan daftar informasi yang dikecualikan. Penilaian website meliputi domain resmi pemkab/pemkot yang mencantumkan menu atau link PPID. Tujuan pemeringkatan menurut Ketua KPID Jateng Rahmulyo Adiwibowo adalah memacu badan publik agar mampu meningkatkan pelayanan informasi. ${ }^{15}$

Riset indeks transparansi informasi publik dilakukan oleh Fitra bersama Partnership for Governance Reform pada Juni-September 2013 di 98 kabupaten di 5 provinsi (Kalbar, Jateng, NTT, Aceh, Sumut) dengan metode penelusuran situs (website tracking). Hasilnya menempatkan Kebumen sebagai kabupaten dengan nilai tertinggi $(48,25)$ dari skala penilaian 0-100. Kabupaten di Jateng mendominasi posisi 10 besar terbaik secara nasional, secara berurutan: Kebumen, Jepara, Nagan Raya, Kudus, Labuhan Batu, Purworejo, Sikka, Magelang, Cilacap, dan Pemalang. Adapun peringkat teratas dalam daftar pemerintah paling berintegritas berdasarkan survei KPK 2013 teratas diraih Kota Bitung Sulawesi Utara disusul Surabaya Jatim, dan Parepare Sulsel. Upaya berupa perbaikan mekanisme pengaduan masyarakat, penggunaan teknologi informasi untuk mempermudah layanan serta perilaku birokrat, layanan pengadaan barang dan jasa, dan pengguna layanan dalam upaya pencegahan korupsi. ${ }^{16}$ Pihak yang dijadikan obyek pelaksanaan IP tersebut belum menyasar pada perpustakaan kampus.

\section{Dampak Tidak Terbukanya Informasi}

Akses publik terhadap sumber dan penggunaan dana lembaga negara yang bersumber dari APBN/APBD oleh lembaga negara seharusnya dibuka secara lebar sesuai aturan main yang tertuang dalam UU KIP. Tidak transparannya penyelenggara negara menyimpan persoalan karena rentan disalahgunakan oleh oknum yang tak bertanggung jawab. Forum Indonesia untuk Transparansi

${ }^{15}$ Suara Merdeka, 17 Desember 2013, hlm.12.

${ }^{16}$ Kompas, 17 Desember 2013, hlm.23. 
Anggaran (Fitra) menemukan empat potensi kebocoran APBN 2013 yang rentan dimanfaatkan untuk kepentingan politik dalam Pemilu 2014. Pertama, BUMN menjadi sapi perahan karena ketidaktransparanan. Dari perhitungan anggaran 2012, nilai penyertaan modal negara mencapai Rp 677,3 triliun. Dari perhitungan BUMN, ternyata ada laba yang ditahan sebesar Rp 407,5 triliun dan ada niat di kalangan BUMN untuk menggunakan anggaran sebagai dana untuk kepentingan politik. Hal ini terbukti pengajuan uji materi UU Keuangan Negara yang dipisahkan dari keuangan negara sehingga tunduknya pada UU Perseroan Terbatas (PT). Terdapat 15 BUMN yang tak rugi tetapi tidak menyetorkan laba dalam kurun waktu 2010-2012 padahal diberi tambahan penyertaan modal negara dengan total $\mathrm{Rp} 4.308$ triliun. Kedua, ada alokasi dana optimalisasi sebesar Rp 26,9 triliun yang syarat kepentingan menjelang tahun 2014, tanpa dibarengi evaluasi kinerja kementerian atau lembaga dan berpotensi menjadi dana titipan menjelang Pemilu 2014. Ketiga, program populis dengan total Rp 52,9 triliun berupa bantuan siswa miskin, program keluarga harapan, Sistem Jaminan Sosial Nasional, dan Program Nasional Pemberdayaan Masyarakat (PNPM) yang berpotensi sebagai alat mobilisasi di daerah. Keempat, Fitra menyoroti bantuan sosial Rp 75,7 triliun yang tersebar di 14 kementerian atau lembaga. ${ }^{17}$ Hasil penelaahan Badan Akuntabilitas Keuangan Negara (BAKN) terhadap ikhtisar hasil pemriksaan semester I tahun 2013 Badan Pemeriksaan Keuangan (BPK) ditemukan kasus penyimpangan keuangan negara dan tata kelola di 21 obyek pemeriksaan BUMN dengan 510 kasus penyimpangan sebesar Rp 2,69 triliun. Dengan rincian 234 kasus terkait kelemahan sistem pengawasan internal dan 276 kasus terkait ketidakpatuhan terhadap ketentuan perundangan, 28 kasus ketidakefektifan senilai Rp 44,75 triliun di beberapa BUMN karena tidak tepat sasaran. ${ }^{18}$

\footnotetext{
${ }^{17}$ Kompas, 16 Desember 2013, hlm.4.

18 Suara Merdeka, 21 November 2013, hlm.2.
} 


\section{Urgensi Keterbukaan Informasi Publik oleh \\ Perpustakaan Kampus}

Pentingnya informasi bagi publik tentu bagian dari upaya untuk mengurangi ketertinggalan publik terhadap dinamika kehidupan berbangsa dan bernegara. Dalam konteks pelayanan publik oleh penyelenggara negara di tingkat kabupaten/kota, jenis penilaian mencakup kategori keberadaan pejabat pengelola informasi dan dokumentasi (PPID), pelayanan informasi, website, serta sarana dan prasarana. Untuk PPID mencakup kelengkapan peraturan bupati/wali kota, surat keputusan bupati/wali kota, dan aturan pelayanan informasi (standar operasional prosedur/ SOP). Pelayanan informasi meliputi jenis informasi berkala, informasi setiap saat, informasi serta merta, dan daftar informasi yang dikecualikan. Hasil penilaian KPID provinsi berupa pemeringkatan bertujuan meningkatkan kinerja dan kompetisi keterbukaan informasi.

Adapun keberadaan perpustakaan kampus sebagai sumber IP, hal yang harus dilakukan meliputi penyelenggara pelayanan perpustakaan kampus, jenis penilaian mencakup kategori keberadaan pejabat fungsional pengelola informasi dan dokumentasi perpustakaan (Pustakawan), pelayanan informasi, website, serta sarana dan prasarana. Untuk PPID mencakup (1) sarana dan fasilitas perpustakaan beserta kelengkapan mengakses melalui information technologi (IT), (2) aturan pelayanan informasi (standar operasional prosedur/SOP). Pelayanan informasi meliputi jenis informasi berkala, informasi setiap saat, informasi serta merta, dan daftar informasi yang dikecualikan, dan (3) produk hukum (undang-undang/UU, peraturan pemerintah/PP, peraturan menteri (Permen), dan kebijakan hukum lainnya yang di-upload dalam web perpustakaan kampus setiap saat menyangkut perguruan tinggi. Hal ini untuk mempermudah publik mengakses informasi publik dalam ruang dan waktu tak terbatas sehingga dengan mudah dilakukan evaluasi dan klarifikasi. Begitu pula bila informasi tentang pelanggaran hukum lainnya, tetapi bentuk pelanggaran 
tersebut diinformasikan kepada publik secara luas maka tindak kriminal akan tercegah. ${ }^{19}$

\section{Urgensi Dunia Maya sebagai Pemasok Informasi Publik antara Manfaat dan Madlorot}

Seiring berkembangnya alat teknologi di bidang informasi, pemasok informasi dapat memerankan media sosial (layanan yang dapat menghubungkan orang per orang dan sekupnya luas untuk diakses publik) secara online (akses langsung) sebagai sumber informasi seperti black berry messanger (BBM), facebook (FB), twitter atau lainnya. Kondisi tersebut direspon oleh perusahaan telekomunikasi global seperti Microsoft, Yahoo, Google, Facebook, Apple, Skype, Youtube, Verizon, AT\&T, dsb. Pengguna informasi melalui dunia maya tersebut lintas batas wilayah sehingga memiliki nilai manfaat dengan prinsip cepat, akurat, dan tidak meluangkan waktu untuk mobilisasi publik. Hal ini merupakan imbas revolusi informasi yang dimotori oleh perkembangan teknologi komputer, telekomunikasi bergerak, dan sistem posisi global. Revolusi ini mengubah cara kita berinteraksi yang telah menghilangkan dimensi ruang. Teknologi ini memungkinkan penyebaran informasi secara langsung menjangkau banyak orang.

Pengguna internet di Asia berdasarkan data Internet World Stats hingga Desember 2011 tertinggi adalah Jepang (101,2 juta), India (121 juta), China (513 juta), dan Indonesia (55 juta) pengguna. Menurut staf ahli Kemenkoinfo, Kalamullah Ramli, pengguna internet di Indonesia pada 2012 terdapat 62,5 juta orang, 67 persennya berusia 14-24 tahun dan 23 persen berusia 25-34 tahun. ${ }^{20}$ Data International Telecommunication Union, pengguna

${ }^{19}$ Sebagai contoh konteks lain, dalam UU No 5/1999 tentang Konservasi Sumber Daya Alam Hayati dan Ekosistem Pasal 21 ayat 2 huruf a jo Pasal 40 ayat 2 dan PP No 7/1999 bahwa satwa yang dilindungi (tidak boleh diperjualbelikan) berupa kucing emas (hidup di wilayah Asia Tenggara), kucing hutan, burung hantu, burung alap-alap, burung elang, kijang, landak, trenggiling, kukang, beruang madu (khas di Provinsi Bengkulu), harimau Sumatera (di Sumatera), macan tutul, macan dahan (di Kalimantan dan Sumatera), kijang muntjak, kambing hutan (di Sumatera), dan burung rangkong.

${ }^{20}$ Kompas, 29 Mei 2013, hlm.12. 
Ponsel dunia pada 2010 mencapai 5,4 miliar, pada 2012 mencapai 6,8 miliar. Diprediksi pada 2013 mencapai 7,5 miliar dan 2016 diprediksi mencapai 8,5 miliar. Pada 2013 52,3 persen pengguna ponsel di Asia Pasific, terbanyak di China (1,1 miliar) dan India (906 juta). Pada 2016 diprediksi mencapai 54,3 persen. Pelanggan Ponsel di Indonesia per Desember 2012 menurut MobiThinking mencapai 260 juta dengan penduduk per Desember 2012 sebanyak 242,3 juta. Dengan demikian, jumlah ponsel yang beredar lebih tinggi daripada jumlah penduduk yakni 107,3 persen karena seorang memiliki lebih dari satu ponsel. Dari jumlah tersebut, 47,6 juta atau 19 persen pengguna 3G/3,5 G.

Pemanfaatan ponsel dikembangkan untuk jejaring sosial (facebook, twitter, foursquare, instagram, dan Path) yang mendongkrak penjualan ponsel pintar (smartphone) yang dapat digunakan untuk mengakses internet, berkamera, membaca teks dalam bentuk word, excel, dsb. Bahkan media ngobrol online dapat dimanfaatkan di Yahoo Messenger, WhatsApp, WeChat, Kako Talk, dan Line yang semua aplikasinya dapat diunduh di ponsel pintar, tanpa SMS. Akses internet yang tersedia di berbagai tempat memudahkan pengguna ponsel pintar mengoptimalkan perangkatnya untuk bekerja dan menikmati hobi. Ponsel pintar berkembang sejak tahun 2000 diawali hadirnya Ericsson T36 yang memiliki Bluetooth, tahun 2002 muncul ponsel pintar Blackberry 5810, Blackberry PDA pertama memiliki konektivitas seluler dengan jaringan GSM, memudahkan kirim dengan elektronik, mengelola data, dan mempersiapkan memo. Tahun 2002 juga muncul ponsel pintar berkamera, seperti Sanyo SCP5300 dengan resolusi 640x480 dan hanya 4x digital zoom (masih sederhana). Tahun 2007 Apple memunculkan ponsel pintar iPhone yang mengganti keyboard dan keypad dengan tampilan layar multisentuh. Tahun 2012 ponsel pintar mampu merekam video 1080p, memutar film, dan mobile hotspot bagi perangkat lain. International Data Corporation (IDC) Januari 2013 menyebutkan 
5 ponsel pintar terjual adalah Samsung (215,8 juta), Apple (135,9 juta), Nokia (35,1 juta), HTC (32,6 juta), Blaccberry (32,5juta), dan ponsel lain 260,7 juta. Jumlah ponsel pintar total yang terjual pada data Januari 2013 sebanyak 712,6 juta. Kehadiran tablet sempat menimbulkan perdebatan apakah perangkat ponsel atau laptop dengan koneksi 3G. data IDC Desember 2012 tablet terjual 122,3 juta tablet, iOS Apple terjual 53,8 persen, Android 42,7 persen dan Windows 2,9 persen. ${ }^{21}$ Data ComScore Februari 2012 bahwa 33 persen pengguna jejaring sosial di dunia berada di kawasan Asia Pasific, di Eropa 30 persen, Amerika Utara 18 persen, Amerika Latin 10 persen, dan sisanya di kawasan Timur Tengah dan Afrika hanya 9 persen. Data akhir 2012, 43,8 juta penduduk Indonesia termasuk pengguna jejaring sosial Facebook dengan urutan Amerika, Brazil, India, dan Indonesia. Adapun pengguna twitter Indonesia urutan kelima tertinggi di dunia. ${ }^{22}$

Di sisi lain, media sosial mudah dikacaukan oleh tangan jahil untuk kepentingan tertentu, sebagaimana selama 2011-2013 awal, Indonesia diserang sebanyak 3,9 juta kali di dunia maya dari dalam dan luar negeri terhadap beragam situs dan sistem yang dikendalikan pemerintah. Gangguan tersebut mayoritas bermotif ekonomi. Kemenkoinfo mengupayakan perlindungan pada dunia bisnis dan instalasi vital seperti listrik, penerbangan, bursa efek, data penduduk elektronik dari gangguan peretas. ${ }^{23}$ Bahkan situs web Presiden Susilo Bambang Yudhoyono (www.presidensby.info) (saat itu) diretas oleh Wildan Yani Ashari, usia 20 tahun warga Desa Balunglor, Kecamatan Balung, Jember, Jatim diadili di Pengadilan Negeri Jember pada Kamis 11 April 2013. Wildan didakwa lima dakwaan berlapis dan dituduh melanggar UU Telekomunikasi dan UU Informasi dan Transaksi Elektronik. Wildan memuat akun domain Presidensby.info di server pihak perusahaan web positioning dan menempatkan file "Jember Hacker Team" di

${ }^{21}$ Adhi, 2013:70. 2013, hlm.71.

${ }^{22}$ Tjahja Gunawan Diredja. Media Sosial untuk Apa? Kompas, 28 Juni

${ }^{23}$ Kompas, 3 April 2013, hlm.5. 
server Jatirejo.com. Akibatnya, para pemakai internet tidak dapat mengakses konten www.presidensby.info tapi konten yang terakses adalah tampilan file HTML Jember Hacker Team. Pada awal April 2013, Presiden SBY menghadirkan dua akun twitter: Istana @Istana Rakyat dan Presiden Susilo Bambang Yudhoyono @ SB Yudhoyono merupakan kehendak presiden menyapa publik dan mencegah terjadinya diskoneksi dengan realitas sosial warga negara.

Data harian Kompas, kriminalitas yang bermula dari media sosial (chatting, friendster, facebook) berupa penipuan, penculikan, perampokan, dan penganiayaan yang berakhir dengan kekerasan seksual bahkan pembunuhan. Terdapat 14 kasus penipuan, 1 kasus pembunuhan, dan 6 kasus kekerasan seksual selama 2002-April 2013 berawal dari 'pertemuan' di media sosial. Pada 2012 Komnas Perlindungan Anak mencatat dari 87 kasus pelecehan seksual terhadap anak, 37 di antaranya berawal dari media sosial. Pada Januari-Februari 2013 dari 216 laporan kasus kekerasan seksual terhadap anak, 31 kasus berawal dari media sosial. Modusnya berkenalan lewat situs jejaring sosial yang ditindaklanjuti pertemuan 'kopi darat' sehingga terjadi kekerasan seksual, perampokan dan penganiayaan. ${ }^{24}$ Menurut Liye, dampak negatif dunia maya menjadi penyakit sosial berupa (1) berkurangnya kualitas dan kuantitas membaca (apalagi menulis teks) mengandalkan akun e-mailnya, (2) suburnya kebiasaan berdebat yang tiada manfaat, (3) tumbuhnya mental gratisan karena mampu mengakses film, lagu dan lainnya secara gratis tanpa memedulikan hak cipta karena asal comot, (4) rendahnya sopan santun karena tak bertatap muka dalam berinteraksi sehingga (sering) menampakkan identitas palsu, (5) mulai kaburnya interaksi dunia nyata, (6) berkurangnya waktu produktif karena terbawa dinamika informasi yang baru dan tidak selalu bermanfaat untuk kehidupan. ${ }^{25}$

Langkah Indonesia menyikapinya dengan menyiapkan keamanan siber dan menyusun langkah koordinasi, di antaranya

\footnotetext{
${ }^{24}$ Kompas,15 April 2013, hlm.27.

25 Tere Liye. Penyakit Sosial Dunia Maya. Kompas, 6 Juli 2013, hlm.7.
} 
dibentuk Indonesia Security Incident Response Team on Internet Infrastructure (ID-SIRTII) yang melibatkan Kemenhan, Kemeninfokom, dan Lembaga Sandi Negara. Dalam konteks global, perang konvensional berupa angkat senjata dengan ledakan bom dan meriam, tetapi dalam era maya dikenal cyber war (perang siber). Sebagaimana sasaran yang 'ditembakkan' pada jaringan milik Amerika berupa jaringan listrik, sistem transportasi, jaringan keuangan, dan militer. Kejahatan ini dianggap lebih bahaya daripada kejahatan transnasional, terorisme, dan proliferasi senjata pemusnah massal. Jenderal Keith Alexander, Komite Angkatan Bersenjata, AS yang memimpin Unit Cyber Pentagon bahwa jumlah serangan maya terhadap situs utama AS makin berlipat yakni lebih dari 140 serangan di Wall Street selama Oktober 2012 hingga Maret 2013. Menurut Pimpinan Eksekutif Google, Eric Schmidt bahwa peretas China yang paling canggih dan produktif menyasar perusahaan AS. Begitu pula Amerika menyerang dengan menyebarkan virus Stuxnet pada 2010 disasarkan pada jaringan nuklir Iran. ${ }^{26}$

Media online dapat diberi makna media massa yang menyajikan berita/info secara online yang tersedia di website/ situs berita. Pada awalnya media online dibuat oleh redaktur media massa cetak untuk memindahkan isi pemberitaan ke website. Media online pertama kali adalah Chicago Online yang diluncurkan oleh Chicago Tribune di Amerika yang tayang perdana pada Mei 1992 sehingga dijuluki The First Newspaper Service on America Online. Adapun media online di Indonesia pertama kali diluncurkan oleh Republika.co.id pada 17 Agustus 1995, disusul Kompas.com., Tempointeraktif.com., Detik.com. Media online tersebut dapat dimanfaatkan sebagai media dakwah. Sebagaimana komunitas Online The Revert Muslims Association (RMA) sejak 2005 tergerak untuk menyelamatkan para calon mualaf ataupun muslimin baru di ranah maya. Mereka membuat situs web menjangkau 85 negara yang bertujuan memberikan pengetahuan

\footnotetext{
${ }^{26}$ Republika, 18 Maret 2013, hlm.27.
} 
keislaman dengan baik dan benar. Web RMA berisi pengetahuan dasar Islam, tata cara ibadah, cerita mualaf, dan forum online untuk memberikan kesempatan para pengunjung web bertanya bebas dan menyampaikan pendapatnya. ${ }^{27}$

Besarnya peran dunia maya sebagai media informasi tersebut maka banyak pengembang membuat aplikasi smartphone (telepon pintar) dengan sistem operasi iOS, Android, Windows Phone, maupun BalckBerry yang aplikasinya dapat diunduh melalui App World. Pertama, al-Quran digital yang diberi nama iQur'an Lite. Aplikasi ini dapat diunduh dan dipasang secara gratis pada smartphone berbasis iOS seperti iPhone, iPad atau iPod dan pengguna ponsel Android. Dengan aplikasi ini, pengguna dapat membuka kitab suci al-Quran kapanpun dan di manapun. Aplikasi ini juga menampilkan terjemahan setiap ayat dengan multibahasa disertai audio yang dapat dijadikan panduan membaca al-Quran dengan tartil. Pengguna juga dapat menandai batas akhir bacaan (book mark) bila pada kesempatan lain ingin melanjutkan bacaan. Kedua, memandu bagi pengguna untuk menentukan arah kiblat dan mendengar azan jika sudah masuk waktu salat sesuai tempat dan lokasi. Ketiga, doa harian disertai suara atau audio yang memudahkan dalam melafalkan doa. Keempat, aplikasi radio dakwah untuk smartphone Android. Siaran radio yang disediakan aplikasi meliputi Radio Rodja Bogor, Radio Muslim Yogyakarta, Radio Al Iman Surabaya, Radio Hangfin Batam, Radio Assunnah Cirebon, Radio Hidayah Pekan Baru Riau, Radio Suara Quran Solo, Radio Kita Madiun, Radio BASS Salatiga, Radio Nurussunnah Semarang, Radio Arroyyan Gresik, dan Radio Islamic Centre Bin Baz Yogyakarta. Kelima, aplikasi Islam menjawab yang menyajikan kumpulan tanya jawab seputar kehidupan sehari-hari. ${ }^{28}$

\footnotetext{
${ }^{27}$ Republika, 23 Juni 2013, hlm.24.

${ }^{28}$ Suara Merdeka, 8 Juli 2013, hlm.19.
} 


\section{B. Simpulan}

Keterbukaan IP bagi lembaga negara (termasuk perguruan tinggi karena mendapat bantuan APBN/APBD) lembaga tersebut terikat kewajiban sebagai badan publik. Setiap badan publik wajib mengangkat pejabat pengelola informasi dan dokumentasi (PPID) yang tugas pokoknya mendokumentasikan dan melayani permintaan informasi bagi publik. Perpustakaan kampus sudah sewajarnya memenuhi amanat UU KIP sebagai penyelenggara negara yang taat hukum yakni adanya pustakawan yang bersertifikasi agar manajemen perpustakaan perguruan tinggi profesional. Apabila kampus mampu melaksanakan dengan baik dan hasilnya dapat dipahami warga negara dengan baik pula maka mewujudkan pembangunan nasional di bidang informasi publik di perpustakaan kampus menjadi kenyataan. Publik dalam mengikuti dinamika perguruan tinggi berdasarkan upaya bersama antara penyelenggara perpustakaan dengan birokrat kampus. Hal ini merupakan satu kesatuan tunggal menuju terwujudnya masyarakat yang cerdas mendapatkan informasi. Negara pun dituntut untuk mengevaluasi kinerja organnya dalam melaksanakan amanat UU KIP.

Pelayanan informasi dibatasi oleh hukum. Pasal 6 (3) IP yang tidak dapat diberikan oleh BP sebagaimana dimaksud pada ayat 1 adalah (a) informasi yang dapat membahayakan negara; (b) informasi yang berkaitan dengan kepentingan perlindungan usaha dari persaingan usaha tidak sehat; (c) informasi yang berkaitan dengan hak pribadi; (d) informasi yang berkaitan dengan rahasia jabatan; dan/atau (e) IP yang diminta belum dikuasai atau didokumentasikan. Pasal 7 (1) BP wajib menyediakan, memberikan dan/atau menerbitkan IP yang berada di bawah kewenangannya kepada pemohon IP, selain informasi yang dikecualikan sesuai dengan ketentuan. (2) BP (perpustakaan kampus) wajib menyediakan IP yang akurat, benar, dan tidak menyesatkan. (3) Untuk melaksanakan kewajiban sebagaimana dimaksud ayat 2, BP (perpustakaan kampus) harus membangun dan mengembangkan 
sistem informasi dan dokumentasi untuk mengelola IP secara baik dan efisien sehingga dapat diakses dengan mudah oleh publik tanpa dibatasi ruang dan waktu. (4) BP (perpustakaan kampus) wajib membuat pertimbangan secara tertulis setiap kebijakan yang diambil untuk memenuhi hak setiap orang atas IP. (5) Pertimbangan sebagaimana dimaksud ayat 4 antara lain memuat pertimbangan politik, ekonomi, sosial, budaya, dan/atau pertahanan dan keamanan negara. (6) Dalam rangka memenuhi kewajiban sebagaimana dimaksud ayat 1 s.d 4 BP (perpustakaan kampus) dapat memanfaatkan sarana dan/atau media elektronik dan nonelektronik. Pasal 8 Kewajiban BP yang berkaitan dengan kearsipan dan pendokumentasian IP dilaksanakan berdasarkan peraturan perundangan. Pasal 4 (1) setiap orang berhak memperoleh IP sesuai ketentuan UU KIP, (2) setiap orang berhak (a) melihat dan mengetahui IP; (c) mendapatkan salinan IP melalui permohonan sesuai dengan UU KIP; dan/atau (d) menyebarluaskan IP sesuai dengan peraturan perundangan, (3) setiap pemohon IP berhak mengajukan permintaan IP disertai alasan permintaan tersebut, (4) stiap pemohon IP berhak mengajukan gugatan ke pengadilan apabila dalam memperoleh IP mendapat hambatan atau kegagalan sesuai ketentuan UU KIP.

UU No 12/2012 tentang Pendidikan Tinggi (PT) Pasal 3 PT berasaskan kebenaran ilmiah; penalaran; kejujuran; keadilan; manfaat; kebajikan; tanggung jawab; kebhinnekaan; dan keterjangkauan. Poin-poin tersebut dapat diwadahi dengan mengoptimalkan pelayanan perpustakaan kampus merujuk pada UU KIP mengikuti dinamika perkembangan IT dalam pelayanan. 


\section{Daftar Pustaka}

Alafghani, Mohammad Mova. Dua Kubu Transparansi. Republika, 28 September 2013.

Diredja, Tjahja Gunawan. Media Sosial untuk Apa? Kompas, 28 Juni 2013.

Hakim, Heri Abi Burachman dan Wiyarsih. Kompetensi Pustakawan dan Optimalisasi Teknologi Informasi untuk Meningkatkan Kualitas Layanan Pemustaka Difabel. Jurnal Ikatan Pustakawan Indonesia. Vol.3, No.1 Tahun 2018.

Liye, Tere. Penyakit Sosial Dunia Maya. Kompas, 6 Juli 2013.

UU Nomor 43 Tahun 2007 tentang Perpustakaan

UU Nomor 14 Tahun 2008 tentang Keterbukaan Informasi Publik (KIP) 